\title{
Imeretian oak and a great capricorn beetle - the problem of relations on the territory of Ajameti Managed Reserve (Republic of Georgia)
}

\author{
Iryna Matsiakh ${ }^{1} \bowtie$, Volodymyr Kramarets $^{1}$, Khatuna Tsiklauri $^{2}$ \\ ${ }^{1}$ Ukrainian National Forestry University, Research and Education Institute of Forestry and Park Gardening, \\ Gen. Chuprynka 103, 79057, Lviv, Ukraine, phone+380952291087, e-mail: iramatsah@ukr.net \\ ${ }^{2}$ Ministry of Environment and Natural Recourses Protection, Agency of Protected Areas, G. Gulua 6, 0114, \\ Tbilisi, Georgia
}

\section{Abstract}

The old-growth endemic Imeretian oak [Quercus robur subsp. imeretina (Steven ex Woronow) Menitsky, 1968] is a protected relict Tertiary period tree still preserved in Ajameti Managed Reserve (Republic of Georgia). For a long time, these forests were experienced to the strong anthropogenic influence. The old-age oak trees and the development of root and stem rot have promoted the settlement of great capricorn beetle [Cerambyx cerdo Linnaeus, 1758 (Coleoptera: Cerambycidae)]. Both of species are protected under the EU Habitats Directive and listed in the IUCN Red List of Threatened Species. The investigation of settling degree of C. cerdo was conducted at two areas, Ajameti and Vartsikhe, on the edge and in the middle of oak forests in June and October 2014. On both the areas, the number of trees with fly exit holes of great capricorn beetle was higher on the margin of forests where plantations suffer greater of human impact. The number of fly exit holes of imago is significantly increased due to deterioration of sanitary condition of forests. The measures of management conservation at Ajameti Managed Reserve were proposed.

\section{KeY WORDS}

endemic oak forests, saproxylic beetle, protected areas, Cerambyx cerdo, Caucasian region

\section{INTRODUCTION}

Imeretian oak (Quercus robur subsp. imeretina) is a protected relict Tertiary period tree in Ajameti Managed Reserve (Firsov 1998). It was first described in 1968 (Euro+Med 2006+; Menytskiy 1971), and nowadays, it is recognised by the majority of dendrologists (Catalogue of Life: 30 July 2015). Moreover, Q. robur subsp. imeretina is a rare endemic tree of Colchis low- land (Kolkhida) in western Georgia and on the small places along the Black Sea in Russia. It belongs to the family of Fagaceae and is spread only in Georgia, especially in its western part, and can also be found in Abkhazia, Lower Svaneti, Racha-Lechkhumi, Samegrelo, Imereti, Guria and Ajara; as relatively significant woodland, it is represented only in Imereti region (Report on forest pathology study of Ajameti Strict Nature Reserve 2007). 
However, the impact of anthropogenic factors (deforestation because of agricultural activities, cutting down trees for timber and fuel, etc.) led to the reduction of $Q$. robur subsp. imeretina areas (Nakhutsrishvili 2013). According to the data of Gulisashvili et al. (1975), Imeretian oak forests grow only in the eastern part of West Georgia on a heavy and clay soil with deep level of groundwater (6-8 $\mathrm{m}$ and deeper). This region has a soft maritime climate and high precipitation throughout the year, which to some extent compensates depth of groundwater. Climate is conducive to frequent repetition of productive years and the acorns begin to germinate in the autumn (Gulisashvili et al. 1975). The composition tree forest stands also includes Georgian oak (Quercus petraea subsp. iberica (Steven ex M. Bieb.) Krassiln.), Zelkova trees (Zelkova carpinifolia (Pall.) C. Koch), Oriental hornbeam (Carpinus orientalis Mill.), European hornbeam (Carpinus betulus L.). Imeretian oak can also form the monodominant tree stands. Imeretian oak appears singly or in groups in the forests of the northwestern part of Colchis lowland. Imeretian oak adapts well to the long-term summer draughts at the places; does not grow well on bad non-developed, macadam and detritus lands; and grows well on the clayey soil (Report on forest pathology study of Ajameti Strict Nature Reserve 2007).

The previous forest management on these areas determines the current state of Ajameti's oak forests. The presence of old-growth oak forests in densely populated area is due to this area being guarded as hunting grounds for Georgian kings. Ajameti forest was one of the beloved hunting areas for Georgian kings for centuries and thus is well protected. It was also the ancestral allod of the King Solomon of Imereti (Report of forest pathology study of Ajameti Strict Nature Reserve 2007).

In Ajameti Managed Reserve, the oak trees have been damaged by great capricorn beetle for a long time. The great capricorn beetle (Cerambyx cerdo) together with the other major xylophages and saprophagous, in particular with stag beetle (Lucanus cervus Linnaeus, 1758) and hermit beetle (Osmoderma sp.), refer to the umbrella species that represent the diversity of the endangered fauna associated with old oaks (Buse et al. 2008; Ducasse and Brustel 2008; Chiari et al. 2012). C. cerdo is explicitly protected under the EU Habitats Directive (Council of the European Commu- nities 1992), classified as globally vulnerable according to the IUCN Red List of Threatened Species (The IUCN Red List2015) and is nearly a threatened species in Europe (Nieto and Alexander 2010). C. cerdo disappeared in the United Kingdom (Alexander 2002); its population is rapidly reducing in the northern part of the areal (Sláma 1998; Ehnström and Axelsson, 2002; Starzyk 2004; Jurc et al. 2008; Ellwanger 2008), but it is still relatively high on the south, in particular on the Caucasus (Sláma 1998; Sama 2002; Miroshnikov 2009). The centres of $C$. cerdo mass reproduction had been observed in different years on the Caucasus: in Georgia and Abkhazia (Lozovoy 1965; Rudnev 1957), Armenia (Mirzoyan 1977), Azerbaijan (Samedov 1963) and the North Caucasus (Dobrovolsky 1951; Miroshnikov 2009). Miroshnikov (2009) points out that on the Black Sea coast in recent decades, the $C$. cerdo population remains high, although it occurs on the small areas or on the individual trees.

Morphological features of great capricorn beetle is very well studied (Rudnev 1957; Lozovoy 1958b; Sama 2002). It is known that the larvae of $C$. cerdo develop mainly in the trunks, branches and even roots of oldgrowth oaks (Quercus spp.), but chestnut (Castanea sativa), probably elm (Ulmus sp.) and common walnut (Juglans regia), can also be inhabited (Sláma 1998). Their development takes three or more years and imago (24-65 mm long) active from May to August, with peaking in June and early July (Heyrovský 1955; Sláma 1998; Sama 2002). The typical oval exit holes up to $20 \mathrm{~mm}$ wide on the trunk or thick branches can be the typical signs of adults' recent activity (Buse et al. 2007). Also, it is provided that beetle prefers old, sunexposed trees and some characteristics of tree such as tree vitality, age, trunk diameter, thickness of bark, distance to the next colonised tree and trunk insolation increase the probability of the occurrence of C. cerdo (Sláma 1998; Buse et al. 2007). In the literature, $C$. cerdo is considered to be a physiological and technical pest. At the beginning, the first year larvae feed itself in the thickness of bark only on alive but weakened tree, then they move under the bark deep into the wood where they make feeding road in length from 40-60 to $100 \mathrm{~cm}$ even next years (Lozovoy 1958b; Sama 2002). The distribution of $C$. cerdo in a landscape and amongst trees are described very well (Buse et al. 2007, 2008b) and the distribution of C. cerdo exit holes 
in old open-grown oaks in relation the height above the ground, shading, cardinal orientation and diameter of the parts of the trunk inhabited were studied by Albert et al. (2012). Rudnev (1957), who studied the development of $C$. cerdo in the forests of Ukraine, Abkhazia and Georgia, considered that great capricorn beetle is only populated on live but weakened trees and stumps of fresh oaks. Other tree species, in his opinion, are very rarely inhabited. However, many authors believe that the great capricorn beetle is a feature of the wider stern specialisation. According to the data of Samedov (1963), in Azerbaijan, C. cerdo often appears in orchards and deciduous forests. Miroshnikov (2009) and Albert et al. (2012) indicate a wide range of forage species of $C$. cerdo. The settlements of great capricorn beetle were found only on two species of oaks in Ajameti - Imeretian oak and Iberian oak.

Some papers note that the improper management and industry caused the distribution of this pest during the second half of 19th century in Ajameti oak stands, and according to the data of Supatashvili et al. (1967), by the 1950s of the 20th century, the number of trees occupied by C. cerdo was about $13 \%$. Rudnev (1957) showed that the population of great capricorn beetle in Ajameti Managed Reserve ranged from 9\% (in the middle of forest) to $29-42 \%$ in the areas near the village. A survey conducted in 2007 indicated that C. cerdo may widely spread within the oak stands and since that $20 \%$ of forest has been damaged (Report on forest pathology study of Ajameti Strict Nature Reserve 2007).

Our primary goal was to assess the current health status of Imeretian oak forests on the territory of Ajameti Strict Nature Reserve, to determine the impact of great capricorn beetle on their conditions owing to many years of exploitation and to propose the measures to further forest management in these forests stands.

\section{MATERIAL AND METHODS}

The field research was conducted in June and October 2014 on the territories of two woodlands areas in Vartsikhe and Ajameti (Ajameti Managed Reserve). A total of four sampling plots were established: two on the edge of forests (per 60 trees on each plots) and two in the middle of the forests (per 115 trees on each plots) in two research localities. The study of the sanitary condition of forest plantations was conducted using the forest-pathological examination. Six categories of tree sanitary condition were determined for oak tree stands on each plots (Vorontsov et al. 1991): I, healthy trees (normal tree stands without features of affection); II, weakened trees (local weakening of branches and affection by pests); III, strongly weakened trees (strong weakening of branches, slight weakening of the trunk, local features of affection by pests); IV, dried trees (drying branches, strong weakening of trunk, large-scale features of affection by pests); V, dead trees of current year (dried branches and trunk, large-scale features of affection by pests); and VI, deadwood of previous years (dried destroying branches and trunk, total development of pests). All trees were numbered on each sampling plots and measured for their diameter at breast height in each plots and classified according to IUFRO criteria based on the recognition of two main aspects of trees: the biological (height class, vitality, developmental tendency) and the silvicultural or economic (stem quality) (Leibundgut 1958; Ouellet and Zarnovican 1988). For establishing the features of distribution of great capricorn beetle and the sanitary condition of Imeretian oaks in Ajameti Managed Reserve, the all trees count was conducted using 'research lines' (Mozolevskaya et al. 1984). These lines had been built in the tree stands the degree of human impact with the account the number of paths and roads, places of grazing were taken into consideration. These lines had been built diagonally in the forests to ensure that all trees were included with taken into consideration the degree of human impact and the account the number of paths, roads and places of grazing. The presence of fly exit holes of a great capricorn beetle was calculated and recorded for every tree.

For estimation, IUFRO criteria (height class, vitality, developmental tendency), advanced models (generalised linear/nonlinear (GLZ) models) and basic statistic (tables and banners, Pearson chi-square) were used in Statistica 10 (StatSoft Inc. 2011) software. Nonparametric statistics and two-by-two tables dialogs were used for the assessment total amount of Imeretian oak trees inhabited by C. cerdo between and inside of the examined places. The impact of categories of the sanitary conditions and the diameter of the trees on the population of $C$. cerdo were evaluated using the GLZ models and analysis of covariance (ANCOVA). One-way analysis of variance (ANOVA; tests of homogeneity of 
variances: Cochran $\mathrm{C}$, the Bonferroni post-hoc test) was used for showing the impact of category of the sanitary condition on the degree of settling trees by great capricorn beetle. The Bonferroni post-hoc test was conducted to determine if there were differences between each categories of sanitary conditions. The Shapiro-Wilk test $(p<0.05)$ was used for checking whether the data is normally distributed for each group and assessed by boxplots. Homogeneity of variances was violated and assessed by inspection of each boxplot.

\section{Results}

In total, 350 oaks were observed on the territory of two places in Ajameti Managed Reserve (includes two woodlands, Ajameti and Vartsikhe). The mean of diameter (at $1 \mathrm{~m}$ above the ground) with the standard deviation $(S D)$ of tree were $34.1 \mathrm{~cm}( \pm 8.5)$ at Vartsikhe edge of forest, $52.6 \mathrm{~cm}( \pm 8.5)$ at Vartsikhe central part of forest and $53.8 \mathrm{~cm}( \pm 13)$ and $49 \mathrm{~cm}( \pm 8.8)$ at the Ajameti edge and central part of forest, respectively.

Statistical analysis showed no dependencies between trees classified according to the IUFRO criteria and the settling degree of great capricorn beetle. The sanitary condition of oak forests was the main parameter that determined the number of oak trees inhabited by $C$. cerdo. Generally, 866 fly exit holes of C. cerdo were recorded. In the surveyed oak stands, the fly exit holes were mainly concentrated at the bottom of the tree up to $2-2.5 \mathrm{~m}$ from the base of the trunk. Only on one tree, where the main branch was broken by the wind, fly exit holes of $C$. cerdo were located at 4.5-5 $\mathrm{m}$ from the base of trunk.

The survey conducted on the territories of Ajameti and Vartsikhe has shown that the percentage of trees inhabited by great capricorn beetle was larger on the edges and lower in the central parts of both research places (Fig. 1).

Nonparametric statistical analysis showed a significant difference between the numbers of trees inhabited by $C$. cerdo in the central and outer parts of each forest plots. For Imeretian oak forests on the territory of Ajameti strict reserve, test revealed that V-square = $4.02, \mathrm{df}=1$ and $p=0.0449$, and for Vartsikhe's oak forests stands, test revealed that V-square $=4.92, \mathrm{df}$ $=1$ and $p=0.0266$. The deterioration of the sanitary condition on the number of growing trees inhabited by C. cerdo was detected (Fig. 2). During the surveys, the trees of category I of the sanitary conditions with fly exit holes of great capricorn beetle were not revealed. The percentage of the trees populated by C. cerdo varied from $34.8 \%$ (category II - weakened trees) to $90.9 \%$ (category $\mathrm{V}-$ dead trees this year).

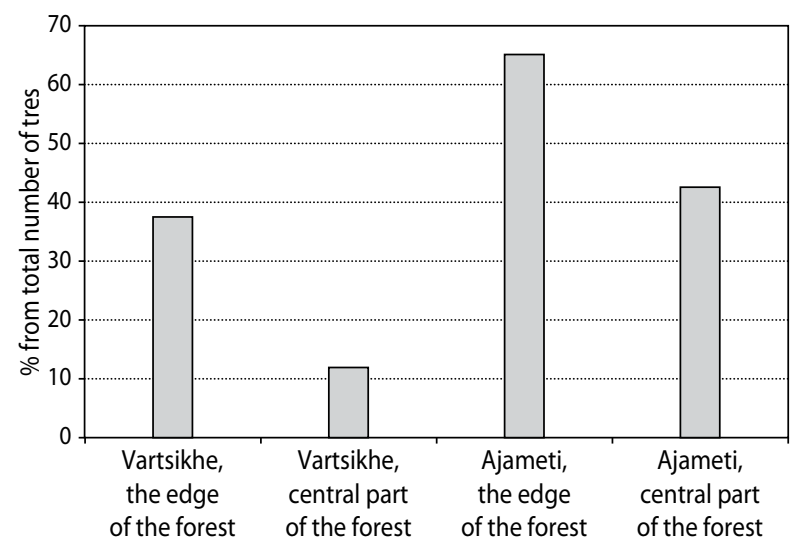

Figure 1. Number of trees inhabited by C. cerdo (\% from the total number of examined trees)

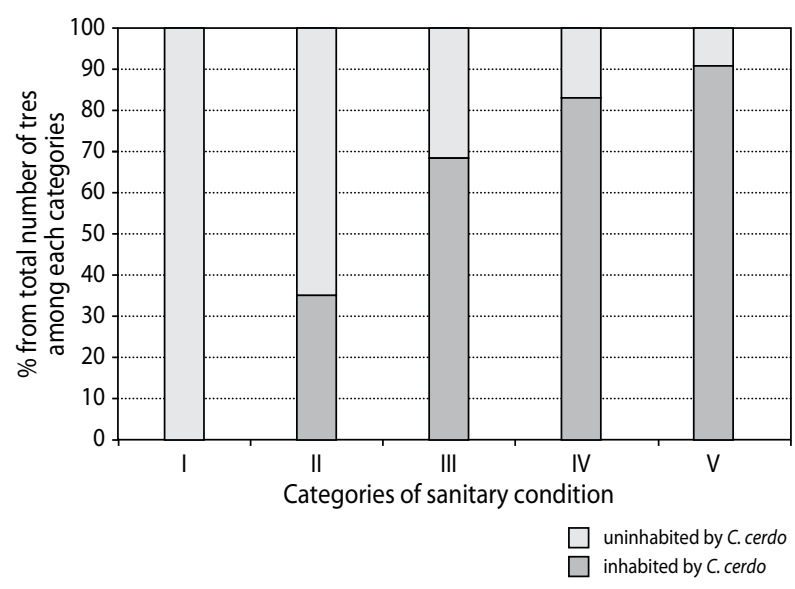

Figure 2. Percentage of trees in the different categories of sanitary conditions inhabited by $C$. cerdo

According to the results of GLZ models for all examined trees, the diameter of trees has no significant influence on the distribution of great capricorn beetle in Imeretian oak forests (Chi-Square $=1.31959$; $p=0.2500665)$ but the category of sanitary conditions of trees affected significantly on it (Chi-Square 
$=26.03517 ; p=0.0000009)$. GLZ analysis for trees inhabited by $C$. cerdo showed that the number of fly exit holes on one trunk was positively affected by the diameter and the category of the sanitary condition of this tree and interaction of both these effects (Tab. 1).

Table 1. Results of statistical estimation of the diameter and the sanitary condition of examined trees on the number of fly exit holes on the one estimated oak trunks (GLZ, Distribution: Binomial, Link function: Logit, Ch-Square)

\begin{tabular}{|l|c|c|c|c|}
\hline \multicolumn{1}{|c|}{ Effect } & $\begin{array}{c}\text { Degr. of } \\
\text { Freedom }\end{array}$ & $\begin{array}{c}\text { Log- } \\
\text { Likelihd }\end{array}$ & Ch-Square & $\mathrm{p}$ \\
\hline Intercept & 1 & -763.481 & & \\
\hline Diameter & 3 & -448.035 & 630.8927 & 0.000000 \\
\hline Category & 1 & -422.878 & 50.3144 & 0.000000 \\
\hline $\begin{array}{l}\text { Diameter* } \\
\text { Category }\end{array}$ & 3 & -414.771 & 16.2130 & 0.001025 \\
\hline
\end{tabular}

Statistical analysis determined the significant difference between the distribution of great capricorn beetle (number of fly exit holes) in trees in the different categories of sanitary condition (Tab. 2).

There was statistically significant difference between the numbers of fly exit holes in trees of categories II, III and IV of sanitary conditions compared to category V. Also, the interaction of diameter and categories of health conditions has a significant influence on the distribution of C. cerdo. Essentiality of the joint impact of interaction of diameter and categories of sanitary condition of oak trees (II and III) to the numbers of fly exit holes compared to category $\mathrm{V}$ were statistically confirmed. On the other hand, significant differences between the joint impact of interaction of diameter and categories of sanitary conditions of oaks between dried trees and dry trees of current year (categories IV and V) were not detected. Significant impact of categories of sanitary condition on the distribution of great capricorn beetle $(\mathrm{F}=28.233, \mathrm{df}=3.70$, $p<0.0001$ ) was detected.

The Bonferroni post-hoc test (Tab. 3) also revealed a significant difference between the degree of settlement (number of fly exit holes of C. cerdo) on the trees of categories II and III of sanitary conditions compared to the trees of other categories of sanitary conditions. There were no statistically significant difference between categories IV and V of sanitary conditions (Fig. 3) but the number of fly exit holes on the dried trees of current year (category IV) is higher than that on the dried oaks (category V; Fig. 3).

Table 3. Results of statistical differences between each categories of sanitary conditions

\begin{tabular}{|c|c|c|c|c|}
\hline \multicolumn{5}{|c|}{ Bonferroni test; variable log N (fly exit holes all) } \\
Probabilities for Post Hoc Tests \\
Error: Between MS $=0.26298, \mathrm{df}=70.000$ \\
\hline \multirow{2}{*}{ Category } & $\{1\}$ & $\{2\}$ & $\{3\}$ & $\{4\}$ \\
& 1.5428 & 2.2388 & 2.8777 & 3.0530 \\
\hline II & & 0.000029 & 0.000000 & 0.000000 \\
\hline III & 0.000029 & & 0.006449 & 0.000274 \\
\hline IV & 0.000000 & 0.006449 & & 1.000000 \\
\hline V & 0.000000 & 0.000274 & 1.000000 & \\
\hline
\end{tabular}

Table 2. Results of statistical estimation the settlement of great capricorn beetle (the number of fly exit holes) in the trees in different categories of sanitary conditions (GLZ, Distribution: Binomial, Link function: Logit, Wald Stat.)

\begin{tabular}{|l|c|c|c|c|c|c|c|}
\hline \multicolumn{1}{|c|}{ Effect } & $\begin{array}{c}\text { Level of } \\
\text { Effects }\end{array}$ & Estimate & $\begin{array}{c}\text { Standard } \\
\text { Error }\end{array}$ & Wald Stat. & $\begin{array}{c}\text { Lower CL } \\
95 \%\end{array}$ & $\begin{array}{c}\text { Upper CL } \\
95 \%\end{array}$ & $\mathrm{p}$ \\
\hline Intercept & & 1.17597 & 0.136758 & 73.94015 & 0.90792 & 1.44401 & 0.000000 \\
\hline Category & II & -2.12437 & 0.319580 & 44.18765 & -2.75074 & -1.49800 & 0.000000 \\
\hline Category & III & 0.51200 & 0.183263 & 7.80529 & 0.15281 & 0.87119 & 0.005209 \\
\hline Category & IV & 0.93712 & 0.217009 & 18.64803 & 0.51179 & 1.36245 & 0.000016 \\
\hline Diameter & & 0.01899 & 0.002585 & 53.94580 & 0.01392 & 0.02405 & 0.000000 \\
\hline Diameter* Category & 1 & 0.01323 & 0.006108 & 4.68811 & 0.00125 & 0.02520 & 0.030372 \\
\hline Diameter* Category & 2 & -0.01267 & 0.003474 & 13.30466 & -0.01948 & -0.00586 & 0.000265 \\
\hline Diameter* Category & 3 & -0.00497 & 0.003939 & 1.59225 & -0.01269 & 0.00275 & 0.207005 \\
\hline Scale & & 1.00000 & 0.000000 & & 1.00000 & 1.00000 & \\
\hline
\end{tabular}




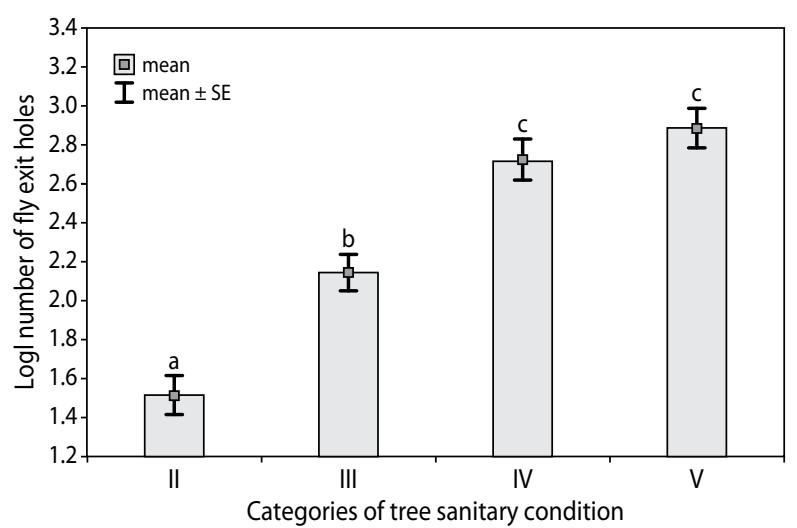

Fig. 3. The number of fly exit holes of $C$. cerdo on the trees in different categories of trees sanitary condition (similar letters indicate the groups that did not significantly differ)

\section{Discussion}

The decrease in great capricorn beetle habitats under the influence of cutting mature forests and as a result of reducing the number of separately growing old oaks caused a decrease in the number of this species within its global population (Nieto and Alexander 2010).

On the territory of Ajameti Managed Reserve, there is a conflict of interests between the two species, which should be protected, Imeretian oak and the great capricorn beetle. In our opinion, this centuries-long conflict was laid by economic forest management activity in oak forests on the territory of Ajameti Managed Reserve. Rudnev (1957) showed that in the early 19th century, the great capricorn beetle was not directly involved in the destruction of oak forests in Ajameti Managed Reserve. First, root rot caused the deterioration of oak forests, and before the massive development of C. cerdo, there the intensive economic activity conducted in the past has reduced the biological sustainability of the forests and as a result of cattle drives, conditions for the distribution and development of great capricorn beetles have been created (Shavliashvili et al. 1980).

During our study, the large number of oak trees vegetated origin was observed on the current territory of Ajameti Managed Reserve. According to the data of Makhatadze and Urushadze (1977), Imnadze et al. (1989), Gigauri (2000), 70-75\% of oak stands in the Ajameti Managed Reserve are of vegetative origin. These are less resistant to unfavourable factors and of- ten affected by root rot, which in turn contributes to the further weakening of trees and creates conditions for the development of great capricorn beetles and other xylophagous beetles. The presence of a significant number of older trees damaged by root rot and other factors is a prerequisite for long-term existence of mass reproduction of C. cerdo.

Albert et al. (2012) indicates the strong relationship between the diameter of tree and the number of fly holes on the tree. Also, this study revealed that the number of exit holes in the trunks of large, open-grown oaks was positively associated with the diameter of the trunk and openness and negatively with height above the ground, and the effects of diameter and openness changed with height (Albert et al. 2012). In the oak forests of Ajameti Managed Reserve, the fly exit holes of great capricorn beetle were often concentrated in the lower part the tree trunk (up to 1.5-2 m), but one tree with processions and fly exit holes of C. cerdo at a height of $4.5 \mathrm{~m}$ with broken thick branch was also found during the survey.

The physiological condition of the tree plays a decisive role in the settlement of great capricorn beetle (Rudnev 1957; Albert et al. 2012). Our research also showed that the determining criterion for settlement of great capricorn beetle is the sanitary condition of trees, and the more weakened trees are more suitable for settlement and development of C. cerdo.

Meanwhile, the scientists and environmentalists pay more and more attention to the preservation of dead wood in the forest. WWF believes that the existence and the condition of the dead wood are a kind of practical indicator of the health and biodiversity of forests (Dudley and Vallauri 2004). Dead wood is a natural component of healthy forest. The presence of rotten wood creates the favourable conditions for the development of saprotrophic or saproxylic organisms (Nieto and Alexander 2010). The presence of dead wood in forests is considered as a way to improve forest management in the direction of convergence with the natural ecosystems. Sustainable management and forest conservation cannot be maintained without a significant number of fungi, vertebrate and invertebrate organisms that are functionally linked to the dead wood in forest ecosystems (Dudley and Vallauri 2004). The protection of many species of vertebrates in particular bats and bird species that nest in hollows trees is a very important task, which is solved in the case of conservation for- 
ests with dead wood. In our opinion, the old trees and dead wood should be maintained and protected on the territory of Ajameti Managed Reserve based on the following requirements of the WWF (Dudley and Vallauri 2004): identifying and protecting key sites to maintain essential reference forests for deadwood species; developing effective strategies for deadwood management within protected areas and Natura 2000 sites; stopping removal of veteran trees and dead wood within IUCN categories I-IV protected areas; strengthening prevention, information and education; and using active restoration measures where needed. The old-growth oak forests play an important role in fixation and preserving the carbon in ecosystems. This is one way to reduce the amount of greenhouse gases in the atmosphere (McPherson and Sundquist 2013). That is why, Ajameti oak forests also play an important ecological role and need to be protected and conserved.

However, many old-aged and dead oaks may be the cause of possible social conflicts with local people who consider the dead wood only as an opportunity to get wood for heating. Therefore, the presence of dead and fallen trees by wind is perceived as forest mismanagement and as a source of the spread of diseases and pests to the healthy tree stands. For our opinion, a very important problem for Ajameti Managed Reserve is that the process of Imeretian oak natural regeneration is not satisfactory. That is a threat of function to those unique forests in the future. Self-seedlings of oak die under a closed canopy of trees or shrubs damaged by root pathogens and powdery mildew. oak plantations Useless perform any actions, it is possible to gradually replace Imeretian oak forests on the derivative forests of hornbeam, maple or, at best way, in the forests of Iberian oak. Without measures to restore the Imeretian oak is the danger of gradual replacing these unique forests on the derivative hornbeam, maple forests or, as the best way, on the Iberian oak forests.

The active measures against great capricorn beetle in Ajameti are not needed. Greater attention should be focused on the reproduction of Imeretian oak stands by promoting its natural regeneration or, if necessary, planting oak forests. For the derived plantings that had emerged because of forest management in previous decades, it is worth to provide reconstruction of these tree stands. On the territory of Ajameti Managed Reserve, the process of falling away old-growth trees is ongo- ing (owing to the presence of stem rot and damages by wind, they breaking down). As a result, there are two possible scenarios.

1. The natural regeneration of Imeretian oak in the areas where it is fallen down by wind can lead to the gradual formation of different ages tree stands. For intensification of the process of natural regeneration in the conditions of the nature reserves, the creation of under canopy stands and partial planting cultures by sowing Imeretian oak acorns should be performed.

2. The growth of secondary tree species and shrubs (including rhododendron and cornusets) in the gaps that are being arisen. In this case, undesirable change in tree species will take place with the formation of derived tree stands with a predominance of hornbeam, Zelkova and maples in tree stands compositions.

Moreover, the work of cutting down and removal of old decline trees, dead wood and wind fallen trees should be limited because such elements are associated with the rare species of mosses, lichens and insects - xylophagy (including great capricorn beetle and other species).

During the forest management operations, it is necessary to distinguish areas where processes of functioning of the old-growth oak stands (like natural forests) are the best occurred. These places can be a kind of 'cores of biodiversity' and should be placed in the middle of the forest, away from roads and livestock routes places. Moreover, the activities should be limited except perhaps only promotion of Imeretian oak natural regeneration. The protection and conservation of the old-growth forests including the one damaged by stem rot or dead trees is currently considered as an important task for foresters and environmentalists (Dudley and Vallauri, 2004). The conservation activities on the territory of the Ajameti Reserve should be developed according to the three directions: (1) protection and conservation of the best-preserved areas of the old-growth Imeretian oak stands, (2) restoration of forests stands with a predominance of Imeretian oak in trees composition and (3) activities in the field of environmental education, tourism and recreation.

During the forest management planning activities, a scheme of functional zoning of the reserve and differentiated regalement for conservation activities of its 
various parts should be developed. It is possible to select areas such as:

1. The zone of special protection. It should include the best-preserved old-growth Imeretian oak stands. It is not necessary to perform any economic activities to avoid disturbances in natural processes.

2. The areas where it is needed to carry out forestry activities for the support of Imeretian oak natural regeneration and the maintenance of existing selfseeding. Such activities should be conducted to prevent the overgrowth of grasses (in particular blackberries) in the gaps inside tree stand and to thin out (cut) self-seeding shrubs and secondary tree species in order to ensure the better conditions for growth and development of Imeretian oak self-seeding. If self-seeding process is characterised by insufficient quantities, it is also necessary to carry out the sowing of Imeretian oak acorns.

3. The area of derivative stand. In the derived stands with a predominance of hornbeam or Zelkova, the measures to reconstruct and restore Imeretian oak forests on such areas should be conducted.

4. The strongly affected areas with paths, roads and trampled grass large places. The measures to restore of Imeretian oak stands on these territories will require long-term efforts and considerable resources. Whilst creating the under canopy plated stand, it is necessary to fence the young trees and prevent their damage or trampling by wild animals and livestock. Ajameti Managed Reserve consists of three clusters of different sizes. The Ajameti station is the most promising for restoring of Imeretian oak. The smaller clusters - such as Vartsikhe and Sviri - require a different forest management regime. The forest management must correspond to the state of Imeretian oak stands in different parts of the reserve in order to be able to decide whether the selection of certain areas and the possible mode of economic intervention are reasonable.

\section{Conclusions}

The current state of Imeretian oak stands at Ajameti Managed Reserve is the result of long-term human impacts (including logging, grazing cows and pigs) that is continued to the present. The presence of a significant number of weakened oaks creates the appropriate con- ditions for the development and distribution of C. cerdo. Forest management on this territory should be focused on the protection, the conservation of old-growth oak stands and the reconstruction of derivative tree stands with the main aim of recreating the origin type of Imeretian oak forests.

\section{Acknowledgements}

This research was made possible by funding from the European Neighborhood and Partnership Instrument East Countries Forest Law Enforcement and Governance II Program (the 'Program') and supported by the European Commission and other donors contributing to a special multi-donor trust fund administered by the World Bank.

\section{References}

Albert J., Platek M., Cizek L. 2012.Vertical stratification and microhabitat selection by the Great Capricorn Beetle (Cerambyx cerdo) (Coleoptera: Cerambycidae) in open-grown, veteran oaks. European Journal of Entomology, 109, 553-559.

Buse J., Schruder T., Assmann B. 2007. Modelling habitat and spatial distribution of an endangered longhorn beetle - A case study for saproxylic insect conservation. Biological Conservation, 137, 372-381.

Buse J., Ranius T., Assmann B. 2008b. An endangered longhorn beetle associated with old oaks and its possible role as an ecosystem engineer. Conservation Biology, 22, 329-337.

Catalogue of Life. http://www.catalogueoflife.org/col/ details/species/id/c2896a04d98af8cdb657cda5da706444/source/tree. Assessed 30 July 2015.

Chiari S., Carpaneto G.M., Zauli A., Marini L., Ranius T. 2012. Habitat of an endangered saproxylic beetle, Osmoderma eremita, in Mediterranean woodlands. Ecoscience, 19, 299-307.

Dobrovolsky B.V. 1951. Harmful beetles. Rostov-onDon (in Russian).

Ducasse J.J., Brustel H. 2008. Saproxylic beetles in the Grèsigne forest management. Revue D Ecologie-La Terre Et La Vie, 63, 67-72. 
Dudley N., Vallauri D. 2004. Deadwood - living forests: the importance of veteran trees and deadwood to biodiversity. WWF brochure, Gland, Switzerland.

Ehnström B., Axelsson R. 2002. Insect galleries in bark and wood. ArtDatabanken SLU, Uppsala (in Swedish).

Ellwanger G. 2008. Conservation status of saproxylic beetles listed in Annexes II and IV of the Habitats Directive at a national (Germany) and biogeographical level. In: Saproxylic beetles: their role and diversity in European woodland and tree habitats. Proceedings of the $5^{\text {th }}$ Symposium and Workshop on the Conservation of Saproxylic Beetles (eds.: J. Buse, K.N.A. Alexander, T. Ranius, T. Assmann). Lüneberg,107-118.

Euro+Med 2006+: Euro+MedPlantBase - the information resource for Euro-Mediterranean plant diversity. http://ww2.bgbm.org/EuroPlusMed [accessed 2 Apr 2013].

Firsov G.A. 1998. Quercus robur ssp. imeretina. The IUCN Red List of Threatened Species 1998. http://dx.doi.org/10.2305/IUCN.UK.1998.RLTS. T34682A9877851.en. Assessed 08 July 2016.

Gigauri G.N. 2000. Biodiversity of Georgian mountainous forest ecosystems. In biological and landscape diversity of Georgia. Proceedings of the First National Conference, 28-29 May 1999. WWF Georgia Country Office, Tbilisi, Georgia, 69-82.

Gulisashvili V., Matachadze K., Prylypko L. 1975. The vegetation of the Caucasus. Monograph, Academy of Sciences of the Georgian SSR, Moscow, Tbilisi Institute, Nauka (in Russian).

Heyrovský L. 1955. Fauna of Czechoslovakia. Vol. 5. Longhorn beetles - Cerambycidae. Academia, Praha (in Czech).

Imnadze T.Sh., Tavadze B.L.,Chapidze F.E. 1989. Oak decline. ZashchitaRasteniǔ, 9, 35 (in Russian).

Jurc M., Ogris N., Pavlin N., Borkovic D. 2008. Forest as a habitat of saproxylic beetles on Natura 2000 sites in Slovenia. Revue D Ecologie-La Terre Et La Vie, 63, 53-66.

Leibundgut H. 1958. Empfehlungen für die baumklassenbildung und methodik bei versunchen über die wirkung von waldplegemaßnahmen. In IUFRO Congress (12th Oxford, UK). Proceedings. Oxford, UK, Forestry Commission Vol. 2, Sec. 23:10.

Lozovoy D. 1958b. Great capricorn beetle (Cerambyx cerdo acuminatus Motsch.) in Georgia. Bulletin of the Tbilisi Botanical Garden, 65, 195-203 (in Russian).

Lozovoy D. 1965. Insect pests in the park and forest park plantings of Georgia. DIWillow. Metsniereba, Tbilisi, Georgia (in Russian).

Makhatadze L.B., Urushadze T.F. 1977. Typological classification of forests as the base of forest management in the Caucasus. Lesovedenie, 2, 3-12 (in Russian).

Mozolevskaya E.G., Kataev O.A., Sokolova E.S. 1984. Methods of pathological examination of foci of stem pests and forest diseases. Moscow, Forestry (in Russian).

McPherson B.J., Sundquist E.T. 2013. Carbon sequestration and its role in the global carbon cycle. Geophysical Monograph 183. American Geophysical Union, Washington, DC.

Menytskiy J. 1971. Oaks tree stands in Caucasus. Nauka, Leningrad (in Russian).

Miroshnikov A. 2009. Review of the longicorn beetles genus Cerambyx Linnaeus, 1758 (Coleoptera, Cerambycidae) of the Caucasus. Moscow State Forest University Bulletin, Lesnoyvestnik, 5 (68), 43-55, 220 (in Russian).

Mirzoyan S.A. 1977. Dendrophilous insects of forests and parks in Armenia. Ayastan, Yerevan, Armenia (in Russian).

Nakhutsrishvili G. 2013. The vegetation of Georgia (South Caucasus). Springer, Berlin, New York.

Nieto A., Alexander K.N.A. 2010. European Red List of Saproxylic Beetles. Publications Office of the European Union, Luxembourg.

Ouellet D., Zarnovican R. 1988. Cultural treatment of young yellow birch (Betula alleghaniensis Britton) stands: tree classification and stand structure. Canadian Journal of Forest Research, 18, 1581-1586.

Report on forest pathology study of Ajameti Strict Nature Reserve. 2007. Vasil Gulisashvili Forestry Institute, Tbilisi, Georgia (in Georgian).

Rudnev D.F. 1957. Great oak capricorn beetle in the forests of the Soviet Union. Institute of Entomology and Phytopathology Academy of Sciences USSR. Ukrainian Academy of Sciences Publisher, Kiev (in Russian).

Sama G. 2002. Atlas of the Cerambycidae of Europe and the Mediterranean Area. Volume 1: Northern, 
Western, Central and Eastern Europe. British Isles and Continental Europe from France (excl. Corsica) to Scandinavia and Urals, G. Sama. Nakladatelstvi Kabourek, Zlin.

Samedov N. 1963. Fauna and biology of beetles damaged agricultural plants in Azerbaijan. Publishing House of the Academy of Sciences of the Azerbaijan SSR, Baku (in Russian).

Shavliashvili I.A., Chapidze F.E., Imnadze T.Sh., Todua B.G. 1980. Pests, disease and reasons of oak forest decline in the Ajameti reserve. In: Protection of forest against pests and disease (ed.: I.A. Shavliashvili). Metsniereba, Tbilisi, Vol. I, 5-31 (in Russian).

Sláma M.E.F. 1998. Longhorn beetles - Cerambycidae of the Czech Republic and Slovak Republic. By the author, Krhanice (in Czech).
Starzyk J.R. 2004. Cerambyx cerdo (Linnaeus, 1758), the great capricorn beetle. In: Polska czerwona ksiega zwierzat. Bezkregowce (eds.: Z. Głowacinski, J. Nowacki). IOP PAN, Kraków, AR Poznań, 148-149 (in Polish).

Supatashvili Sh., Mukhashavria A., Chapidze F. 1967.

By the application of control measures against a great capricorn beetle (Cerambyx cerdo acuminatus Motsch) in Ajameti State Reserve. Proceedings the Institute of Plant Protection, 19, 15-21 (in Georgian with Russian abstract).

The IUCN Red List of Threatened Species. Version 2015.2. http://www.iucnredlist.org/details/4166/0. Assessed 20 August 2015.

Vorontsov A., Mozolevskaja E., Sokolova E. 1991. Technology of forest protection. Ecology, Moscow, Russia (in Russian). 